\title{
Beyond Metropolitanism and Nativism: Re-grounding Media Theory ${ }^{1}$
}

\author{
Gholam Khiabany and Annabelle Sreberny \\ Goldsmiths College, University of London and SOAS, University of London
}

\begin{abstract}
While de-Westernisation is an interesting political intervention in media theory, analytically it offers little. We critique this approach through six inter-related arguments. The first point of critique challenges the putative singularity of the West. The second line of enquiry raises questions about the emergence of new academic disciplines and their intellectual offerings. Our third point is that the call to de-Westernise Media Studies is naïve, ignores history and the long patterns of global interconnectedness that have mutually formed the West/Rest. The fourth argument is that "de-Westernisation" suggests that the theory and methods of Media Studies offer nothing of use outside their original birthplaces, while the fifth argument is the conceptual danger of nativism. The sixth critique centres on the problem of essentialising culture as a determinate object. Examining the contemporary media practices of the Islamic Republic of Iran, we suggest that the true alternative to a repressive theocracy is its internal challenge by women, students and other parts of civil society that offers a critical third way beyond the binary divide.
\end{abstract}

Keywords: de-Westernisation, Iran, West/Rest, binary thinking, civil society

Within the academic field of Media Studies there is growing concern over Western parochialism and intellectual hegemony. Repeated calls for its internationalisation have managed to unsettle a number of assumptions and propositions, while calls for "deWesternisation" raise more complex issues. Our aim here is to probe the epistemological limitations of "de-Westernisation" as it is being applied to Media Studies, even as we accept some of its political intentions, and to propound a more nuanced approach to the study of the media in what is often referred to in a highly condensed manner as the "global South". ${ }^{2}$ In addition, we explore how this rhetoric of "de-Westernisation" has been adopted by an authoritarian state in its actual political struggles against Western hegemony. Here, our specific focus will be the media environment of the Islamic Republic of Iran, although we

\footnotetext{
${ }^{1}$ We would like to acknowledge the critical readings of our paper by Mark Hobart and John Downing; any remaining errors are ours alone.

${ }^{2} \mathrm{We}$ are aware of the risks of using such a term, that such a geographic synecdoche cannot do justice to the complexity and internal differentiation of large swathes of peoples and territories and that there is a linguistic crypto-hegemony in assuming the North to be the developed world and the South as that to-be-developed. But we also approach the "West" as a necessary linguistic fiction for much of this essay, even as we try to unpack the term. We hope the ensuing discussion makes our position clear.
} 
hope that some of these ideas are equally applicable in other locations where authoritarian states prevail.

\section{From Internationalising to de-Westernising Media Studies}

Goddard once said of film that each has a beginning, a middle and an end but not necessarily in that order. We might say that all societies have elements that might be called politics, economics and culture but not in the same arrangement. And most also have elements that can be called media. The issue of what exactly are the media, how to theorise and study them and their impacts on and interactions with the other three spheres has never been more vexed.

There is long-standing concern over a "Western bias" in media theory and its negative parochial impact (Downing, 1996). One demand has been to "internationalise" the focus of Media Studies beyond its heavy North Atlantic history and its strong focus on the role of media in supposedly functioning democracies, especially those in Europe. The aim is to take seriously the development of media beyond this geography and to acknowledge its perhaps different dynamics — of development, institutionalisation, practice and content - elsewhere, particularly across Africa, the Middle East and Asia.

Without a doubt, one of the reasons for the emergence of this demand to internationalise Media Studies has to do with the effects of global capitalism and the expansion of a transnational student population into higher education, predominantly from the Rest to the West, despite the despicably high costs. How could "we" continue to ignore the places whence they came or continue to talk about 'their' experiences as if identical to ours? It is ironic that the study of other-non-Western - people's media has fallen under the rubric of "international communication". That had been the part of Media Studies that had hitherto focused on the critical analysis of Western corporate expansion into non-Western societies, arguing that the spread of media was caught up with the putative spread of modernisation processes to the rest of the world; thus, media were seen to be part of the teleology of modernity.

Now, as Western academia is increasingly organised along business models, to produce the kind of graduates coveted by multinationals, it is imperative to interrogate the various agendas involved in drives towards "internationalisation". It appears that as ever more foreign students study in English-speaking universities and as more non-Westerners have been trained in its theories and approaches, Media Studies as an academic field has had to confront its geographic and cultural blind spots. But, ironically, the demand to internationalise the curriculum supports the corporatisation of the university sector in the US, UK and elsewhere by which foreign students are reduced to cash cows. International communication is in danger of merely being the part of media studies that bothers to engage with non-Western societies, without any critical theorisation. As Dirlik neatly puts it:

[T] he cultural requirements of transnational corporations can no longer afford the cultural parochialism of an earlier day. Focusing on liberal arts institutions, some conservative intellectuals overlook how much headway multiculturalism has made with business school administrators and the managers of transnational corporations, who are eager all of a sudden to learn the secrets of East Asian economic success in 'oriental' philosophies, who cannibalise cultures all over the world in order to better market their commodities, and who 
have suddenly become aware of a need to internationalise academic institutions which often takes the form not of promoting scholarship in a conventional sense but of 'importing' and 'exporting' students and faculty. (Dirlik, 1994, pp. 354-5)

Indeed, it is important to recognise that, as national education systems have evolved around the world, Western definitions of academic disciplines and indeed Western intellectual framings of debate have been institutionalised. Sometimes this has meant that a particular and somewhat limited vision of "mass communication research" learned in the graduate schools of the US gets established in universities of the global South without much critical intervention. The work of Carnoy (1974) on educational imperialism comes to mind here.

Of course, the concern with Eurocentrism and the issues of relevance and academic dependency in the social sciences in the global south are nothing new. Amongst others, Edward Said (1979), Samir Amin (1989), Immanuel Wallerstein (1997) and Dipesh Chakrabarty (2000) have all examined how the ideas of "Europe" and the "Orient" were perceived, constructed and articulated. Not only is there epistemic dependency but, as Alatas (1995) rightly suggests, the existence of Orientalism and Eurocentrism cannot be separated from the structure of academic dependency that links core and peripheral social scientists. Social science became institutionalised during European expansion and later the economic hegemony of the United States since 1945, so that native intellectuals, trained in colonial languages and institutions, may share the assumptions of Orientalism and Eurocentrism. Often social scientists in the global South depend on external funds for research and development and the results are published in journals that are mostly controlled and based in North America and Western Europe. The inequality in wealth and power and consequences of the international division of labour (Alatas, 2003) is also mirrored in education and research, according to which "raw data" is exported from the global South to the global North, then shaped into theories and exported back to the South. Thandika Mkandawire, then president of the Council for the Development of Economic and Social Research in Africa, argued that "... one effect of this division of labour is that it pushes African scholars towards local minutiae. This might seem a commendable antidote to the extroverted [i.e., lofty theoretical and even other worldly] discourses on Africa, but as Hountoundji observes, even this focus on the local is externally driven, shaped by the needs of the 'North' and ends up reducing African researchers into "knowledgeable informants"' (cited in Greene, 2003: 141142).

These two parallel processes of "internationalisation"- the circulation of Western academic disciplines into Southern universities and the reverse flow of Southern students into Western universities - have produced more research and engagement with media systems and contemporary cultural practices beyond the "West". This is evident in the increasing number of books, journal articles, conferences in the academic field that are expanding the geocultural spaces of Media Studies into the Middle East, Asia and Africa. However, the demand for and debate around "de-Westernisation" raises other, more fundamental intellectual questions.

\section{Six Critical Issues Regarding de-Westernisation:}

Recently "de-Westernisation" has become a serious analytic approach in Media Studies. 
Consider the work of Curran and Park (2000), Wang (2011) and others. It is often simply taken to be politically progressive and opposed to Western domination, and it is not just the media, but also audiences, internet, film, critical security studies, health planning and even the Gospel that have become the focus of "de-Westernisation". That this analytic category and disciplinary frame is itself the outcome of Western theorisation is frequently overlooked, so that even in the attempt to escape the "West", it is continually reinscribed in a hegemonic manner. Indeed, we might argue that there is no escape, no "outside" in which to find refuge - that will be part of the burden of the rest of our argument.

What is often lost in this general attempt to free media from the straightjacket of Western media theory is any definition of the "West", which we have so far set in quotation marks. "De-Westernisation", a problematic term, seems to assume a single, homogenised and unified West. Equally problematic, the "non-West" is too readily established as a known and knowable entity. And, apparently, never the twain shall meet. In his recent book, Dabashi makes the bold claim that, "Our interlocutor is no longer 'the West', for 'the "West' is dead" (Dabashi, 2012: 251) He argues that the frozen binary of "the West versus the Rest" is finished. He suggests that it is time to move beyond the post-colonial project, which always cast its subjectivity as a negative response to the West, and to start embracing the new worlds and new possibilities that are being born. Given the first term in the quotation above, we have to ask from where he is speaking and presume that it is from a "non-Western" position; otherwise who constitutes the subject of "our/us"? Also key is his use of "the" in making the West a simple singularity. Even if he is hoist by his own language, Dabashi offers a radical invitation for us to think differently. However, he cannot intend us to ignore the ongoing political role of Western countries in contemporary military adventures around the world. Dabashi's claim raises vividly the manner in which epistemological claims have political consequences or allow/refuse certain political positions.

So a first point of critique of de-Westernisation is to ask what is this putative singularity, the West, and what precisely is being critiqued in this conceptual move? This "West" has produced the Holocaust and Hiroshima, multinational banks, the RAND corporation, National Endowment for Democracy and the Ku Klux Klan. But this same West has produced the chartist movement, the suffragettes, civil rights, women and gay movements, the Spanish Civil War and the Occupy movement. In the very same West exist numerous different countries, different socio-political trajectories and varied forms of media, media institutions and practices, with contradictory voices. The literature on deWesternisation is rather silent on these contradictions and fails to specify which geographic or cultural parts of the West is being invoked. At a time when even scholars from different corners of Europe, from Scandinavia to the Iberian peninsula, bemoan the dominance of the English language and Anglo-American literature in the field and are actively pursuing their own cultural projects, a little bit of caution in using the term 'de-Westernisation' can go a long way.

A second line of enquiry might raise questions about the emergence of new academic disciplines and their intellectual offerings. Our reading of the development of Media Studies runs, briefly, like this. As Western states became more complex, so a diversification of knowledge developed and with it the disciplining (a wonderful Foucauldian process of taming knowledge) of non-scientific knowledge. The early $19^{\text {th }}$ Century focus on "political 
economy" fractured into two separate and often non-communicating disciplines of Politics and Economics, as different departments set in different buildings of a university materialised the distinction. Only with the 'global' financial crisis of 2012-2013 has the revival of classic Marxist thinking reminded us of the relevance of the political system in regulating - or, more recently, in not regulating - the economy, the financial sector and taxation.. If Anthropology, a project closely linked to imperialist knowledge, remained focused on the single ethnographic case study of the "Other", Sociology in its pretensions to understand itself, the modernising Western core, offered models of societal dynamics in which the West was always the winner, the most developed, the epitome of the modern. In its grand move toward a theory of the 'global', it has had little pause to rethink its foundational assumptions. The universal project was always profoundly - and still is - about geography. As Harvey shows, even John Locke recognised this: "Without knowledge of geography, gentlemen could not even understand a newspaper." (Locke cited in Harvey, 2009:14)

Media Studies could only develop when media institutions and forms appeared sufficiently developed and autonomous as to warrant their own strands of analysis, even if these continually lead us back into political economy and issues of ownership and control or back toward the cultural specifics of contextualised meanings and practices. Thus, the foundational problem for Media Studies - as with all existing academic disciplines in their current configurations - is its evolution from within a specific time-space configuration of an idealised Western capitalist democracy, which includes the attempts to use this normative framework as a neutral framework for investigating practices of mediated communication in other parts of the world.

Encapsulated in the language of both "Internationalisation" and "de-Westernisation" lies the "spatial turn" within Media Studies, the sudden recognition-triggered perhaps by globalisation as both contested theory and contradictory reality - of the rest of the world and the role played by old and new media technologies in linking the world in various ways. So the understandable and necessary intellectual desire to include and analyse media systems beyond the dominant English-speaking environment is clear. However, the adequacy of the conceptual frame that has emerged to fulfil such a project is another matter.

The third point of our critique is that the call for a "de-Westernisation" of Media Studies is naïve. The blind spot of binary thinking is to ignore history, the long patterns of global interconnectedness that have mutually formed the West/Rest. Conquest, travel and 'civilising missions' have brought together elements of material culture (food, including sugar, tea, coffee, spices; ceramics and pottery; textiles, clothing, carpets; aesthetic practices and art forms), as well as more abstract elements such as shared religious, spiritual and aesthetic values and cultural practices. Bulliet's recent (2004) attempt to address IslamoChristian interactions is exemplary. Islam has a strong presence in London's Whitechapel, while there are many Buddhists in Brooklyn.

Surely the entire history of the world is a history of encounters, adoptions and adaptations, so that the West/Rest do not suddenly discover each other on a particular date, but have known each other forever and are always already imbricated? Certainly, these encounters have not always been staged on an equal footing and the last long period of human history has been heavily biased toward different forms of Western power. But a political desire to produce a new form of knowledge is insufficient to guarantee the clarity of 
the paradigm.

Fourth, "de-Westernisation" seems to suggest that the theory and methods of Media Studies and broader social theory offer nothing of use outside their original birthplaces. Is there nothing of use to be gained from the works of, say, Williams, Habermas and Bourdieu in discussing and understanding media culture in the global South? It seems to us that explorations of concepts such as the "public sphere", the "everyday" and "taste cultures" are not irrelevant in the non-West, even if they present themselves in different formations and locations. These ideas prompt discussion about what constitutes the 'public', how and by whom is "taste" defined and what does the "everyday" mean under different discursive regimes. Attempts to critique the universal pretence of media theory seem to draw a completely parallel universe in which non-Western media and culture are necessarily and distinctly different from the West. The emergence of Bayat's notion of "lived politics", for example, might be seen precisely as a critical engagement with Western theorisation and the development of a concept that comes out of a non-Western political context.

Connell has neatly synthesised some of the problems with the "northernness of general theory" thus:

The consequences of metropolitan geo-political location can be seen...in four characteristic textual moves: the claim of universality; reading from the centre; gestures of exclusion; and grand erasure. (Connell, 2007: 44)

We might quickly — and perhaps ironically — note that the terms in which Connell frames the issues are themselves classic Western articulations - but that, in itself, is not a bad thing! Let us gloss each of her points briefly. First the claim of universality - a term that shares an etymological root with university - is seen to be at the heart of social theory, depending on the assumption that all societies are knowable and knowable in the same way and from the same point of view. The idea that this very point of view originates in the metropole is not explicit-indeed, in Barthian terms, it is exnominated-whereas argument generated elsewhere is deprived of universality because its local specificity is named as such; for example, in "African philosophy". Second, theory as developed in the West often thinks of time in abstract terms, as date-free and continuous - while the histories of most colonial experiences are of discontinuity and abrupt change. Third, authors from the periphery are rarely read and even more rarely acknowledged in the West. Fourth, since social theory is built in dialogue with empirical knowledge, when it is built on the basis solely of metropolitan experience, it erases the experiences of the majority of the world from the foundations of social thought.

It appears that recent claims to "de-Westernise" media studies are somewhat stalled. Curran and Park (2000) merely offer an untheorised model of political, rather than media, differences that hardly develops the debate. Hallin and Mancini are critical enough of their attempt to expand their model of media comparison beyond the Western democracies whence it originated to note "that this enterprise involved a kind of contradiction; it ran the risk of producing exactly the kind of universalising extension of our framework we hoped to avoid" (2012: 3). Interestingly, this growing awareness is still mainly conducted in English and 
expressed mostly in American and British journals, ${ }^{3}$ part of the Anglo-American academicindustrial complex.

So a fifth point in our argument is the conceptual danger of nativism. The quest for "authenticity", assertions of cultural difference and attempts to formulate "native" conceptions of knowledge, all too often reduce forms of culture and identity into singular and all-inclusive constructs. A parallel process is to construct 'insiders' as having better knowledge and understanding than 'outsiders', no matter what theoretical approach they use. This implies that a literal standing-in-place is better than a symbolic standing in theory or politics, rendering the de-Westernising of subject areas-especially Media Studies - the preserve of indigenous elites. But we have already discussed the education and institutionalisation of local elites as itself coloured by Western educations and experiences.

A reductive nativisation, as Dirlik explains, "reveals the impossibility of sustaining reified, holistic notions of traditions, which already have been transformed by modernity, and appear most prominently as sites of conflict between different social interests and different visions of the modern" (2003: 286). Such cultural turns in recent years appear anti-modern and apparently reject modernity but they should be seen precisely as attempts to reconstruct modernity according to particular regional models. Capitalist modernity in its current stage, as Dirlik has argued, "has had to interiorize cultural difference as part of its very constitution; one fundamental consequence of which has been to compromise its identification with EuroAmerican models of modernity, which provided an earlier modernization discourse with its teleological power" (2002: 17). In this sense, cultural traditions that were assigned to the dustbin of history in earlier versions of modernisation have seen a significant development in recent years. For example, the Confucian revival in China, alongside the revival of Hinduism in India, Buddhism in other Asian countries, Islam in much of the Middle East, as well as the revival of a Pan-Turanian utopia in Turkey all point not to a "singular" Asia, nor to a unified "Islamic World", but rather to diverse cultural claims to modernity. As Dirlik (2002) suggests:

[T]oo much preoccupation with Eurocentrism or colonialism also disguises fundamental questions of contemporary modernity that cut across so-called cultural divides, especially as the locations of modernity and culture are themselves thrown into question with the reconfigurations of economic and political organisation globally. Differences framed in terms of geographical or spatial cultural locations serve above all to conceal the fact that these are the least important differences that may matter in an age of globalisation. They are no less anachronistic than the persistence of Three Worlds idea, which informed an earlier modernisation discourse, but they do serve a purpose in the containment of difference.

The turn toward nativism is sometimes a consequence of the call for "indigenisation" of the

\footnotetext{
${ }^{3}$ Such works include a special edition of the journal Media, Culture and Society, Vol. 15(1) (2003) on Islam and Communication; Javnost/Public, Vol. 8(2) (2001), dedicated to Media and Democracy in Asia; Asian Journal of Communication, Vol. 10(2) (2000); Global Media and Communication, Vol. 3(3) (2007); a major conference entitled "Internationalising Media Studies: Imperatives and Impediments", hosted by University of Westminster in 2006; as well as numerous conference panels, seminars, not to mention scores of books and articles.
} 
social sciences, another response to purported academic dependency and mental captivity. Indigenisation, as Alatas argues,

... is an amorphous term. It refers neither to a theoretical perspective nor to an intellectual movement. Rather, it is a loose category that subsumes the works of various authors from a wide variety of disciplines in the human sciences, all of which are concerned with the problem of irrelevancy and the generation of alternative scientific tradition. (1995: 128)

The concern nevertheless goes beyond providing amendments to the parochialism of Eurocentrism, since there are calls for autonomous social science traditions that generate knowledge, concepts and methodologies rooted in a non-Western context. But within this international call to practise relevant social science and to decolonise it, there exists a "nativist" tendency. Sometimes there is a crude ad hominem presupposition that local academics and intellectuals will produce better local knowledge, as if the international dynamics of higher education, dominance of certain paradigms of thinking and social scientific methodologies have not already exacted their toll on creative local thought.

This leads to our sixth critique which centres on the problem of essentialising culture as a determinate object, an argument developed by both Fabian (1991) and Hobart (1990). One example of such an approach was a special edition of Media, Culture and Society (Vol. $15: 1,1993)$, which wanted to "interpret differences of systems of thought with greater understanding and finesse". This was explained in the introduction that blithely utilises a number of essentialising categories:

In this issue, for increasingly obvious reasons, we have taken the risk of trying to dig into some of the roots of current cultural clashes between the Muslim world and the West. Thus, for the first time in a major, Western English-language media and cultural studies journal, we have attempted to put together a collection of analyses of communication and culture by Muslim Scholars and have also sought comments from a leading politician and a prominent religious leader. Our focus, naturally, is upon conceptions of communication as they are theorised by Muslims. (Media, Culture and Society, 1993, p. 5)

It should not be necessary to say that not all Muslims think the same way. Yet, as Khiabany (2011) pointed out, the issue offered five contributions from scholars and politicians from only two countries, Iran and Pakistan, to be representative of "communication as . . . theorised by Muslims". Nor would all Muslim women think in that same way; yet, as Sreberny argued (1993), none had been invited to write for this special issue.

Perhaps no region of the world has been so theoretically strung out between Western notions of modernity and indigenous notions of tradition than the "Middle East", a colonial construct par excellence (Sreberny, 2008). Before the year of magical activity in the Middle East-2011 - the dominant Western conceptual approach was to problematise the "lack of democracy in the region in terms of the stubbornness of 'tradition' and the 'backwardness of Islamic civilisation' to explain 'what went wrong?"' (Lewis, 2002). In this influential mode of thinking, Islam gets treated as a coherent, self-sealed and self-explanatory culture and as the main obstacle in front of Islamic countries seeking full membership of the exclusive club of 'modernity'. Reproducing the old stories of the incompatibility of 'Islam' with 
'modernity', Lewis argued: "The absence of a native secularism in Islam, and the widespread Muslim rejection of an imposed secularism inspired by Christian example, may be attributed to certain profound differences of belief and experiences in the two religious cultures" (2002: 10). This repetition of modernisation theory fails to acknowledge that the question of religious revival is not simply a question for Islam, since it is alive and kicking in many countries including in the US. It is not so much an issue of the clash of tradition with the modern, but the increased visibility of religion's involvement in the clash over the nature of global modernity. ${ }^{4}$

The response in the "Islamic world" to this vision of historical development has been two-fold. Many share the basic assumption of Lewis and others and have begun the process of "self-examination", mapping religious/cultural traits as the key reason for failure in their engagement with modernity (Matin-Asgari, 2004). Others, while challenging the Eurocentrism of "Islamic Studies" and pointing out neglect in recording the contribution of "Islamic civilisation" in science and economy, do share the basic assumption of the "uniqueness" of "Islamic" culture and civilisation. Such an interpretive or explanatory strategy is also evident in the call for the 'Islamisation' of knowledge which is part of a much broader historical trend to Islamicise the social sciences and sociology (Zaidi, 2006; Gole, 2000) and to effect a reconstruction of knowledge from a specifically "Muslim" perspective.

However, behind much of the current discussion about the conflict between fundamentalist Islam and the secular, modern West lie highly romantic and ahistorical notions of both Islamic culture and of the West itself. Many commentators claim that the Middle East is unique; that religion has remained a central and defining feature of the "Islamic World"; that there is a unified history and identity of Islamic culture; that the study of this "history" and "culture" demonstrates, beyond doubt, the incompatibility of Islam and Muslims with modernity; and that for all these reasons the Muslim world remains an "exceptional" case. The conflation of the construct of the Middle East with the "Islamic World" was always problematic, but even more so now as the centre of gravity of the "Islamic World" has shifted east into Asia, to Malaysia and Indonesia (Khalidi, 2003).

To play with the Englishism for a moment, the construction of a political imaginary named "the Middle East" only made sense if one was looking out from a London/Paris axis to the world; but equally, it relied on another pre-established notion, of the "Far East', from which it was to be distinguished. The "Middle East" was at the centre of the ancient Silk Road along which continental and maritime trade routes linked the old empire of China to Europe through India, and the Middle East itself looked East as much as West. The route was so named by the German geographer Ferdinand von Richthofen in 1877 just as European imperialism imposed new territorial divisions that subsequent nationalist movements would later reinscribe.

We do not wish to deny a critique of "Eurocentric" historiography, which has ignored and neglected the immense contribution by others to what we would like to call "human

\footnotetext{
${ }^{4}$ This, of course, has consequences not only for academic scholarship. It lies behind and drives political strategies to 'bring democracy' to the region, and in Europe in the context of 'war on terror' feeds and encourages anti-Muslim racism. For a good analysis of the illiberal rage of liberal intellectuals against Islam, see Kundnani (2008).
} 
civilisation". However, by organising and arranging the world in such neat units (all appearing to possess some unbroken cultural unity and continuity), we only reproduce, by accident or design, the very "Islamic Studies" that has been under attack at least since the publication of Said's Orientalism. Thus, writing on Islamic Studies and the European Imagination, Al-Azmeh has argued:

To this schematization of the self corresponds the schematism of the other. Each of these schemata is a topic which is invariably called forth to schematize things that are observed Islamic. Thus there are 'Islamic cities' unlike all other cities, 'Islamic economies' to which economic reason is inapplicable, 'Islamic polities' impenetrable to social sciences and political sense, 'Islamic history' to which normal equipment of historical research is not applied. Facts are disassociated from their historical, social, cultural and other contexts, and reduced to this substantive Islamism of European imagination. (1993: 139)

Or as Dirlik has rightly argued, "It is one of the profound ironies of our times that modernity should be in question more seriously than ever before at the very moment of its apparent global victory" (2003: 275).

If the critique of Eurocentrism and the parochialism of the social sciences is a "corrective" act and an expression of solidarity with the "non-West", the reception and articulation of this critique in the political dynamics of the global South reveals yet more contradictions. The advocates of "Islamic communication theory", more or less, belong in this camp and many of the contradictions of such an approach can be seen in the history of the Islamic Republic of Iran.

\section{The Iranian Revolution and the Invention of the Islamic Republic}

Iran and the Iranian revolution is often presented as a significant example of the success of the "indigenous", with the transfer of power to a new Islamic theocratic ruling elite viewed as the revenge of 'tradition on modernity' (Mowlana and Wilson, 1990). That Iran had an older indigenous tradition, most often defined by Zoroastrianism, that Islam was brought in by Arab conquest and that the Safavids invented Shi'ism as an idea and practice that separated them from the Ottoman Empire and the Arabs is usefully forgotten - but part of a complex history that we cannot flesh out further here.

The Islamic Republic as articulated by Ayatollah Khomeni was to take on an identity in distinction to the "corrupt West", the "great Satan" of the United States and its predatory political and degenerate culture. Thus, the conceptual rhetoric of the West/Rest binary-or the "de-Westernisation paradigm"- -also became a global political paradigm as used by the Islamic Republic.

Mowlana, once a professor of international communication in the USA, became a key media policy-maker of the Islamic Republic and helped the development of the rhetoric. His trajectory from US-based media scholar to lieutenant of a repressive hegemon is a fascinating one. In Mowlana's "Islamic" response to the "Western" model of communication, one supposedly more in tune with the cultural values and history of the Islamic World, the nationstate is counterposed to the Islamic community, the Umma (community of the faithful in an undifferentiated 'Islam' (Khiabany, 2011) Mowlana brushes aside the material realities of 
capitalist modernity, since in the Islamic model "the central question is not one of economics but of culture, ethics, and tabligh" (Mowlana, 1996: 126). For him, Tabligh (propagation is based on Tawhid (monotheism), which implies the "unity, coherence and harmony" of the universe ... It stands for the necessity of exclusive servitude to and ... negates any right of sovereignty and guardianship over human society to anyone except God (Mowlana, 1996: 119-20). This is the ultimate fetishism of difference that oddly reproduces the Orientalist understanding of "Islam". In its questioning of the relevance of "Western" social sciences, such an approach also questions the relevance of the agencies and subjectivities of all social groups and classes other than the ulema-undermining the twin pillars of velayat-e-faghih and public participation that ground the Islamic Republic - and denies the inclusion of identities based on anything other than the binary of believers and non-believers.

By relegating politics to a realm of "culture", by dehistoricising and decontextualising "culture", by elevating text (holy books) over context, and ideas and the social imaginary over material and social realities, by imagining a past and an authenticity that never was, such claims to difference only succeed in suppressing the internal differences within such a perceived singular "culture". This denial of nations, histories, locations and contexts thus shows itself in the idea of Islamic communication theory. "Islamic" communication theory is neither about the media that are owned by people who are Muslims, nor about those media that are designed for consumption or consumed by Muslims. None of these, as we shall see, makes a channel or a media product "Islamic". What advocates of "Islamic communication" do offer (despite some clear differences in their emphasis and "identity") is reinforcement of the binaristic division of the world into two overly neat categories of the God-fearing Islam and the secular West. Mowlana (1990, 1993, 1994, 1996), Pasha (1993), Sardar (1993), Ayish (2003) and others have tried to free communication theory from its enslavement to Western conceptual orientations and elaborate instead a singular "Islamic perspective on communication". Thus, they neatly erode the long history of intra-Muslim conflicts (one form of which is currently being played out with some relish by Western media as the "Sunni-Shiite conflict") so that the construction of a singular Islamic perspective is too readily achieved. The paradox of the critique of Orientalism is a reproduction of limited and banal postures and a fixation in a dehistoricised frozen binary from which there appears no escape. Hence, the call for indigenisation is too vague, creating a simple mirror opposite of Eurocentrism, and failing to point to a convincing range of examples. It is then no surprise that scholars affiliated to a notion of Islamic communication give very little analysis of the struggle for control over the interpretation of "culture", or of communicative resources, or of the system of social stratification.

Such assertions of cultural differences, as the case of Iran demonstrates, also leave the door open for the manipulation of political power and repressive measures used indiscriminately against Muslims and non-Muslims, secularists and believers, natives and non-natives. A key element of essentialist thinking is reductionism: that is, the reduction of all other identities such as class, gender, ethnicity, regional and political allegiances to one inclusive identity. Within this narrative there is only one way of "imagining community" and that is by religion.

\section{Beyond the False Binary: New Voices Inside the Islamic Republic}


What interests us is the way the much vaunted theory of "de-Westernisation" is played out in the policy and practices of the Islamic Republic, a pre-eminent test case for "Islamic nativism". Here is the ultimate marriage of a conceptual framework stemming from the West, albeit by academics and intellectuals trying to push for a theoretically progressive approach, with a political project of anti-Westernism by an authoritarian state. This project turns in the end not only on the blocking of Western ideas and cultural product, but also on the stymying of internal opposition voices who try to build democratic capacity inside the country. It turns into a model that Gramsci would have recognised well, the appearance of a hegemonic system which — neither very far behind, nor concealed — wields a powerful surveillance and coercive system designed to correct any breaks of conformity.

Dominated by fears of "cultural imperialism" and penetration, latterly renamed as the promotion of "Velvet Revolution", the Islamic Republic has eschewed most Western cultural forms and products. It promotes a particular form of Shi'ite authoritarianism through Islamic Republic of Iran Broadcasting (IRIB), the national broadcaster, the key ideological organisation that offers numerous radio and television channels, book publishing and film production to address different audience niche needs. ${ }^{5}$ IRIB also maintains a significant external broadcasting arm in various languages, including Arabic and English, while its international English-language Press TV supposedly "provides a voice for the voiceless".

But the Islamic Republic has confused the form with the content, so in its paranoia about "cultural threat", it has variously banned the very technologies themselves as carriers of unwanted material. So satellite dishes are illegal, although it is estimated that around 70 per cent of the population has a dish. And in the concern to prevent "Western" cultural content entering the country, little attention is paid to the many channels of pornography produced by many "Islamic" Middle Eastern countries and readily available on the multichannel television packages available to Iranian audiences. While Iranian traditional music is now allowed, many contemporary forms of music are not, driving a lively scene literally underground. Dance is proscribed, theatre limited and non-representational art barely tolerated (Sreberny and Torfeh, 2013). Cartoonists and bloggers, publishers and film-makers have all run into problems, newspapers and journals have been closed and personnel imprisoned, even executed.

But intra-elite contestation has meant that not only cultural forms that might be construed as 'originally' Western have been constrained, but actually much of the worst invective and control has been meted out to participants within the Islamic Republic who do not share the specific political vision of the powers-that-be. Thus, the late Ayatollah Motazeri, conservative newspapers and religious bloggers have all been censored. While fearful of new technologies coming from outside, these have been readily used to broadcast confessions recorded under torture from Iranian prisons.

Ironically, none of this much affects Western cultural producers who have domestic and international markets galore and who find their way into Iran anyway (viz. Murdoch's Farsi One television channel). However, it does severely restrict the cultural habits and tastes

5 Such internal differentiation reminds us of the oft-quoted idea of propaganda, supposedly from Goebbels: "What you want in a media system is ostensible diversity that conceals an actual uniformity." 
of Iranians. But the young are Internet adepts and school themselves well with illegal downloads of music, film, pornography, etc. The black market is flooded with film DVDs and music CDs, often of the most up-to-date releases, many of which are readily available in city bazaars. And beyond the policing of cultural consumption (Sreberny and Khiabany, 2010) lies an extensive fabric of social control, of the policing of everyday life and the surveillance of anything deemed oppositional. These cat-and-mouse politics between the State and the people has produced a schizoid mode of living where maintaining appearances in public is vital for a quiet life, while many people have found ways to satisfy a range of desires quietly within their private homes.

But alternative perspectives have developed within the Islamic Republic that provide a location for internal critique, as well of external critique, that is to say, positions which cannot be swallowed up by either metropolitan universality or nativist hegemony. These two positions are feminism and the development of a civil society voice, positions that are closely intertwined. These have developed over the past three decades of the Islamic Republic as the key sites of resistance to an Islamicised fundamentalism that often masquerades as antiWestern nativism.

\section{Gender and Civil Society as the Internal Oppositional Voices}

Clearly "gender discrimination" is one of the easiest critiques that outside pontificators can make of so-called Islamic societies. But equally, the "de-Westernising" argument has been remarkably silent about gender or minority politics within Southern societies, preferring to use notions of homogeneous culture. We could cite the misuse of the plight of Afghani women and the struggle of RAWA and other organisations by Western politicos, including Laura Bush, in support of US imperialist adventure. Our critique would make the point that this struggle was long-standing but ignored until it became useful for the West to acknowledge it; and equally, by focusing on the struggle that might be pragmatically relevant, the similar plight of women in other locations (Palestine, for example) is still ignored. On the other hand, we are also well aware of the simplistic rejection of women's demands by authoritarian regimes since feminist struggles are 'Western'.

We do not wish to fall into either trap. There are long histories of women's struggles in Iran and the wider region. The real significance of the women's movement since 1979 is its raising of a wide set of issues about gender relations and inequality that includes not only familial issues such as marriage, divorce and child custody, but also labour laws, political participation, lack of independent judiciary, etc. We have written elsewhere (Sreberny and Khiabany, 2010) about the 30-year history of the Islamic Republic, its wars and economic circumstances that have propelled women into the frontlines of political struggle. In relation to the media, we have documented the emergence of a women's press, women bloggers (Sreberny and Khiabany, 2010) and the manner in which women's demands for their human rights is part of a broader struggle for communicative rights inside Iran (Sreberny, forthcoming). Women make up over 60 per cent of university students and have not been prone to Western cultural stereotypes, choosing to study hard sciences, nuclear physics and mechanical engineering. However, suddenly in the summer of 2012, the Islamic Republic decided to proscribe over 70 university subjects to women, impose gender segregation and insist that women to remain in their home town to study. What would be a "de-Westernised" 
agenda in support of women's rights? How might we understand such a system if not through the analytic lens of authoritarian neo-patriarchy?

\section{The Emergence of Civil Society}

Crucially, the women's movement has to be seen as part of the emergence of broader civil society politics in Iran. This was developing before the 1979 Revolution that was its triumphal moment. It was pushed back only to became even more significant in the reform period in the 1990s, inspired by both national and international histories and struggles, theories and authors. The emergence of labour politics, the student movement, increasingly even gay rights are all "indigenous" but draw inspiration from many diverse sources. The 'de-Westernising' argument, like Orientalism, suggests a horizontal methodological nationalism of national cultures doing battle, while the vertical power politics within many societies gets overlooked by both.

Inside Iran, there is a growing cacophony of civil society voices raising questions about corruption, incompetence and making these public. Despite the evident repression, there are many voices - male and female - in newspapers, magazines, blogging and making music and art, raising political issues and attacking the definition and the practice of the 'indigenous' politics of the Islamic Republic. The index of the political tragedy of the Islamic Republic is the number of journalists, editors, bloggers, women's activists, trade union organisers, lawyers, intellectuals who have been killed, have been and are imprisoned, placed under house arrest and otherwise rendered unable to promote public discussion about a wide range of social and political issues. It is in this context that Press TV's claim rings with a hypocritical hollowness and the arguments about "cultural imperialism" or "soft war" are spurious when the main opponents are the internal critics.

This does not mean that there is no external intervention happening. The "sanctions regime" headed by the US and EU is having a devastating impact on the daily lives of many Iranians. ${ }^{6}$ Iran is perhaps the only nation to have felt the brunt of new international forms of "cyber-warfare" through the Stuxnet, Flame and Duqu viruses; and there have been a number of assassinations of Iranian scientists on the streets of Iran. A Media Studies that extends to such issues of cyber-warfare has to recognise that the combatants are not simply the US vs. Islamic Republic, but also the Islamic Republic vis-à-vis many of its people. The third position that gender politics and civil society voices articulate feels the brunt of both imperialism and dictatorship.

In its effort to present itself as a bulwark against US intervention in the Muslim world, Iran rhetorically spins its ability to withstand sanctions as a moral victory against imperialism, while quietly moving forward with its neoliberal economic policies, everincreasing militarisation and suppression of opposition at home. Those close to the regime are benefitting hugely. Porsche have noted that it sold more cars to Tehran in 2011 than anywhere else. Just as in the Iraqi case, US-led sanctions make grassroots democratic dissent much more difficult for ordinary Iranians living in Iran. At the same time, the Iranian government has only tightened its control on the flow of wealth and information in the

\footnotetext{
6 "Sanctions against Iran: a duplicitous "alternative" to war: http://www.jadaliyya.com/pages/index/5518/sanctions-against-iran_a-duplicitous-alternative-t.
} 
country, while the economy dances to the movement of the dollar as never before. In the conflict between empire and dictatorship, there is a great need for a third way beyond the militaristic dance of macabre state-led politics-as-usual. (For a powerful critique of the lack of class analysis in post-colonial theory and the 'specter of capital', see Chibber, 2013)

\section{Conclusion}

The massive amount of engineering required to maintain the appearance of a monolithic Islamic totality suppresses the recognition of internal diversity, not only across a world religion such as Islam, but within a single polity such as the Islamic Republic. Middle Eastern regional exceptionalism opts for a fragmentary mode of analysis and produces culturalist narratives that ignore the broader context of cultural production in particular and capitalist modernity in general. By choosing to focus on 'culture', these narratives not only fail to tackle the question of whose culture, thereby ignoring the fact that culture has always been a site of struggle, but they also separate the question of the 'everyday' from the question of political economy. That danger runs through all simplistic articulations of de-Westernisation, as manifest perhaps in notions of "Asian values" or Hindutva as the expression of Indianess; thus the Iranian case is merely an illustration of politico-cultural issues that have to be addressed in many parts of Asia.

Culture, as Ahmad (2004) has argued, is not just about the past and inheritance, but also about the future (the generation of meanings) and societies are always contradictory totalities of practices, struggles and disputes over imaginings of the future, as well as narratives of the past. Eurocentrism as an intellectual tradition emerged not just in Europe, but in capitalist Europe. The spread of Eurocentrism has accompanied the global spread of capitalism. By diverting criticism of capitalism to criticism of Eurocentrism, shifting attention from political economy (the political, economic and social) to culture, and replacing equality with identity, the advocates of Islamic exceptionalism reveal their own ideological limitations. The challenge to Eurocentrism has to take place not just in the site of culture.

Connell has asked, and not simply rhetorically, "can we have social theory that does not claim universality for a metropolitan point of view, does not read from only one direction, does not exclude the experience and social thought of most of humanity, and is not constructed on terra nullius?" (2007: 47) But she disavows any simplistic return to forms of nativism that have occasionally been put forward as the antidote to Western conceptual dominance.

We have suggested that the voices, demands and practices of women and civil society in Iran, ordinary people - are the real 'contradiction' to an authoritarian political structure, not Hollywood cinema or British television. This challenge will be centered in new forms of citizenship and practice, perhaps in a new cosmopolitan ethos as Dabashi (2012) has put it, that transcends the redundant East/West binary and actually imagines-and perhaps produces - something new.

The rhetorical politics of the imperious binary of the "West/Rest" suggests that nothing "positive" stems from the former, but also that the "Rest" is always benign and progressive. Is it not more important to pay attention to real politics and the shape of power relations on the ground within societies and across international boundaries? The challenge for social analysts is to find a conceptual footing between imperialist intervention on the one 
hand and non-Western exceptionalism on the other, a critical "Third Voice" that goes beyond the binary divide.

\section{References}

Abaza, M. (2007) "More on the shifting worlds of Islam. The Middle East and Southeast Asia: A troubled relationship". The Muslim World 97(3): 419-36.

Ahmad, A. (2004) On communalism and globalization. New Delhi: Three Essays Collective.

— (2008) "Islam, Islamisms and the West", in L. Panitch and C. Leys (eds.) Global flashpoints: Reactions to imperialism and neoliberalism (Socialist Register). New York: Monthly Review Press.

Alatas, S. F. (1995) "The theme of "Relevance" in third world human sciences". Singapore Journal of Tropical Geography 16(2): 123-40.

(2003) "Academic dependency and the global division of labour in the social sciences". Current Sociology 51(6): 599-613.

Al-Azmeh, A. (1993) Islams and Modernities. London: Verso.

Amin, S. (1989) Eurocentrism. London: Monthly Review Press.

Ayish, M. (2003) "Beyond western-oriented communication theories: A normative ArabIslamic perspective". Javnost 10(2): 79-92.

Bayat, A. (2010) Life as politics. Amsterdam: Amsterdam University Press.

Bulliet, R. (2004) The Case for Islamo-Christian Civilization. New York: Columbia University Press,

Carnoy, M. (1974) Education as Cultural Imperialism. New York: John Wiley.

Chakrabarty, D. (2000) Provincializing Europe: Postcolonial thought and historical difference. Princeton NJ: Princeton University Press.

Chibber, V. (2013) Post-Colonial Theory and the Specter of Capital, London: Verso

Connell, R. (2007) Southern Theory: social science and the global dynamics of knowledge. Cambridge: Polity.

Curran, J. and M.-J. Park (eds.) (2000) De-Westernizing media studies. London: Routledge.

Dabashi, H. (2012) The Arab Spring: The End of Postcolonialism. London: Zed.

Dirlik, A. (1994) "The postcolonial Aura: Third world criticism in the age of global capitalism". Critical Inquiry 20(1): 328-56.

(2002) "Modernity as history: post-revolutionary China, globalization and the question of modernity". Social History 27(1): 16-39.

(2003) "Global modernity? Modernity in an age of global capitalism". European Journal of Social Theory 6(3): 275-92.

Downing, J. (1996) Internationalizing media theory. London: Sage.

Fabian, J. (1991) "Culture, time and the object of anthropology", in Fabian, J. ed.) Time and the work of anthropology. New York: Harwood.

Gole, N. (2000) "Snapshots of Islamic modernities". Daedalus 129(1): 91-117.

Greene, S. (2003) "The Multiple Worlds of African Studies", in A. Mirsepassi, A. Bassu and F. Weaver (eds.) Localising Knowledge in a Globalizing World. New York: Syracuse University Press.

Hallin, D. and P. Mancini (2012) Comparing Media Systems Beyond the Western World. 
Cambridge: Cambridge University Press.

Harvey, D. (2009) Cosmopolitanism and the Geographies of Freedom. New York: Columbia University Press.

Hobart, M. (1990) After Culture: Anthropology as Radical Metaphysical Critique. Yogyakarta: Duta Wacana Press. Available at: http://www.criticalia.org/Sources/After\%20culture\%20complete.pdf.

Khiabany, G. (2011) "Whither Eurocentrism? Media, culture and nativism in our time", in G. Wang (ed.) De-Westernizing Communication Research. New York: Routledge.

Khiabany, G. and A. Sreberny (2001) "The Iranian Press and Continuing Struggle over Civil Society 1998-2000". Gazette 63(2/3).

(2004) “The Women's Press in Contemporary Iran: Engendering the Public Sphere”, in N. Sakr (ed.) Women and Media in the Middle East. London: I. B. Tauris.

Kundnani, A. (2008) "Islamism and the roots of liberal rage". Race and Class 50(2): 40-68.

Lee, C. C. (2001) "Beyond orientalist discourses: Media and democracy in Asia". Javnost/the Public 8(2): 7-20.

Lewis, B. (2002) What went wrong? Western impact and Middle Eastern response. New York: Oxford University Press.

Lund, J. (2001) "Barbarian theorizing and the limits of Latin American exceptionalism". Cultural Critique 47: 54-90.

Matin-Asgari, A. (2004) "Islamic studies and the spirit of Max Weber: A critique of cultural essentialism". Critique 13(3): 293-312.

Media, Culture and Society (1993) [Special edition: on Islam and Communcation 15(1)].

Mowlana, H. (1993) "The new global order and cultural ecology". Media, Culture and Society 15(1): 9-27.

(1994) "Civil society, information society, and Islamic society: A comparative perspective", in S. Splichal, A. Calabrese and C. Sparks, (eds.) Information society and civil society: Contemporary perspectives on the changing world order. West Lafayette, IN: Purdue University Press.

(1996) Global communication in transition: The end of diversity. Thousand Oaks CA: Sage.

Mowlana, H. and L. Wilson (1990) The passing of modernity: Communication and transformation of society. New York: Longman.

Pasha, S. (1993) "Towards a cultural theory of political ideology and mass media in the Muslim world". Media, Culture and Society 15(1): 61-79.

Richard, Y. (1995) Shi'ite Islam. Oxford: Blackwell.

Said, E. (1979) Orientalism. New York: Vintage.

Sardar, Z. (1993) "Paper, printing and compact discs: The making and unmaking of Islamic culture". Media, Culture and Society 15(1): 43-59.

Schlesinger, P. (1993) "Islam, postmodernity and the media: An interview with Akbar S. Ahmed". Media, Culture and Society 15(1): 29-41.

Sparks, C. (1998) Communism, capitalism and the mass media. London: Sage.

Spivak, G. C. (1999) A critique of postcolonial reason. Cambridge, MA: Harvard University Press.

Sreberny, A. (1993) “On Reading Islam and Communication”. Media, Culture \& Society 


\section{5(4): 661-8.}

(2008) "The analytic challenges of studying the Middle East and its evolving media environment". Middle East Journal of Culture and Communication 1(1): 8-23.

(forthcoming) "Establishing a 'Rights' regime in Iran: Thinking Communications, Politics and Gender together", in C. Padovani and A. Calabrese (eds.) Communication Rights and Social Justice. Palgrave.

Sreberny, A. and G. Khiabany (2010) Blogistan. London: I. B. Tauris.

Sreberny, A. and M. Torfeh (eds.) (2013) Cultural Revolution in Iran: Contemporary popular culture in the Islamic Republic. London: I. B. Tauris.

Thomaselli, K. (2003) “'Our culture' vs. 'foreign culture': An essay on ontological and professional issues". Gazette 65(6): 427-41.

Wallerstein, I. (1997) "Eurocentrism and its avatars: The dilemmas of social science". New Left Review 226: 93-108.

Wang, G. (ed.) (2011) De-Westernizing Communication Research: Altering Questions and Changing Frameworks. New York: Routledge.

Zaidi, A. H. (2006) "Muslim reconstructions of knowledge and re-enchantment of modernity". Theory, Culture and Society 23(5): 69-91.

Zubaida, S. (1993) Islam, the people and the state: Political ideas and movements in the Middle East. London: I. B. Tauris. 